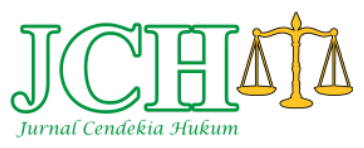

\title{
PENANGGULANGAN PELANGGARAN LALU LINTAS OLEH SATUAN LALU LINTAS POLRES BUKITINGGI TERHADAP PELAJAR
}

\author{
Anny Yuserlina \\ Sekolah Tinggi Ilmu Hukum Putri Maharaja Payakumbuh \\ J1. Sertu Kamaruddin Blok W. No.7 Kel. Sapiran Kec. ABTB Kota Bukittinggi \\ e-mail: annyyuserlina87@gmail.com
}

\begin{abstract}
The use of motorbike vehicles in the city of Bukittinggi is currently very rapid, but not accompanied by an increase will be aware and safe driving, especially for students at the high school/vocational/equivalent level, many who do not meet the safety standards in driving as stipulated in legislation. Bukittinggi is one city that also has a lot of both public and private schools, this also causes the violations committed by the instructor, including not having a SIM (Driving License), not wearing a helmet and changing vehicle standards. The purpose of this paper is to find out and analyze the response to traffic violations committed by students by the Bukittinggi Police Traffic Unit. The problem in this study is how to overcome traffic violations committed by students by the Bukittinggi Police Traffic Unit. To make this system more systematic, the writer uses an empirical juridical approach. The results of this study indicate that in overcoming traffic violations committed by students, the Bukittinggi police traffic unit conducts preventive and respite prevention. The factors that become obstacles in overcoming traffic violations committed by students are: The problem of legal awareness and traffic legal compliance among students is still lacking. Therefore it is necessary to look at the form of response so that it can overcome traffic violations.
\end{abstract}

Keywords: Traffic Unit; Violation; Traffic; Students.

\begin{abstract}
Abstrak
Penggunaan kendaraan sepeda motor di Kota Bukittinggi saat ini sangat pesat, akan tetapi tidak dibarengi dengan peningkatan akan sadar dan amannya berkendara terutama pada siswa di tingkat SMA/SMK/Sederajat, banyak yang tidak memenuhi standar keselamatan dalam berkendaraan sebagaimana yang diatur di dalam peraturan perundang-undangan. Bukittinggi adalah satu kota yang juga banyak memiliki sekolah-sekolah baik negeri maupun swasta, hal ini juga menyebabkan banyaknya pelanggaran yang dilakukan oleh pelajar antara lain tidak memiliki SIM (Surat Izin Mengemudi), tidak memakai helm dan merubah standar kendaraan. Tujuan penulisan ini adalah untuk mengetahui dan menganalisa tentang penanggulangan pelanggaran lalu lintas yang dilakukan pelajar oleh Satuan Lalu Lintas Polres Bukittinggi. Permasalahan dalam penelitian ini adalah Bagaimana penanggulangan pelanggaran lalu lintas yang dilakukan pelajar oleh Satuan Lalu Lintas Polres Bukittinggi. Untuk menjadikan lebih sistematika-nya penulisan ini, penulis menggunakan metode pendekatan secara yuridis empiris. Hasil penelitian ini menunjukkan bahwa dalam menanggulangi pelanggaran lalu lintas yang dilakukan oleh pelajar, satuan lalu lintas Polres Bukittinggi melakukan pencegahan secara preventif dan respresiff. Adapun faktorfaktor yang menjadi hambatan dalam menanggulangi pelanggaran lalu lintas yang dilakukan oleh pelajar yaitu: Masalah kesadaran hukum dan kepatuhan hukum berlalu lintas dikalangan pelajar
\end{abstract}

\footnotetext{
* Naskah diterima: 23 Februari 2019, direvisi: 24 Maret 2019, disetujui untuk terbit: 27 Maret 2019

Doi: $10.3376 /$ jch.v4i2.133
} 
masih kurang. Oleh karena itu perlu dilihat bentuk penanggulangannya sehingga bias menanggulangi pelanggaran lalu lintas.

Kata Kunci: Satuan Lalu Lintas; Pelanggaran; Lalu Lintas; Pelajar.

\section{PENDAHULUAN}

Perkembangan ilmu pengetahuan dan teknologi dewasa ini, menambah pesatnya jumlah produksi kendaraan. Hal ini disebabkan karena adanya faktor kebutuhan manusia yang semakin kompleks, khususnya kebutuhan sekunder. Oleh karena itu, sering terlihat dan terdengar di koran, televisi, radio, atau media massa lainnya. Pelanggaran lalu lintas yang dapat menyebabkan timbulnya korban jiwa dan harta benda merupakan suatu kejadian yang sangat tragis dan merupakan akibat dari kurangnya kesadaran hukum di masyarakat dalam berlalu lintas dan keteledoran para masyarakat pemakai jalan yang terkadang tidak memperhitungkan aspek-aspek yang dapat menjadi penyebab pelanggaran lalu lintas (Soerjono Soekanto: 1980).

Rambu lalu lintas adalah bagian perlengkapan jalan yang berupa lambang, huruf, angka, kalimat, dan/atau perpaduan yang berfungsi sebagai peringatan, larangan, perintah, atau petunjuk bagi pengguna jalan. Undang-undang yang mengatur tentang rambu-rambu lalu lintas telah disahkan oleh pemerintah maka penegakan hukum harus dilaksanakan, dalam hal ini penegakan hukum mengenai lalu lintas dan angkutan jalan merupakan kewenangan Kepolisian Republik Indonesia. Fungsi Kepolisian adalah salah satu fungsi pemerintahan negara di bidang pemeliharaan keamanan dan ketertiban masyarakat, penegakan hukum, perlindungan, pengayoman, dan pelayanan kepada masyarakat (Ayu Yohana Putri: 2015).

Ketidakseimbangan antara daya tampung jalan dengan peningkatan kendaraan, baik kendaraan bermotor roda dua maupun roda empat dan angkutan jalan lainnya yang ada di jalan raya, membawa akibat peningkatan pelanggaran yang berdampak negatif bagi masyarakat. Untuk mencegah pelanggaran lalu lintas semakin meningkat, maka diperlukan adanya kaidah hukum yang merupakan pengamanan agar mencapai ketertiban lalu lintas. Kaidah hukum adalah salah satu kaidah yang diperlukan untuk mengantisipasi permasalahan hukum, termasuk hukum yang mengatur masalah lalu lintas jalan (Kansil, C.S.T: 1995).

Pelajar masih tergolong sebagai anak di dalam pandangan hukum, sebagaimana yang termuat di dalam peraturan perundang-undangan antara lain Undangundang Nomor 35 Tahun 2014 tentang perubahan atas Undang-Undang Nomor 23 Tahun 2002 tentang Perlindungan anak, sebagaimana yang termuat di dalam Pasal 1 ayat (1), Anak adalah seseorang yang belum berusia 18 (Delapan Tahun), termasuk anak yang masih dalam kandungan (R. Soesilo: 1985).

Remaja yang secara psikologis masih berada dalam kondisi labil masih 
Anny Yuserlina: Penanggulangan Pelanggaran Lalu Lintas Oleh Satuan Lalu Lintas...

menangkap hal-hal baru begitu saja, karena belum bisa menyaring hal-hal positif ataupun negatif yang datang atau yang diterima oleh mereka secara akal sehat (R. Soesilo: 1985).

Berkendara yang aman (safety riding) sangat diperlukan di dalam berlalu lintas untuk menjaga kelancaran transportasi, selain itu berkendara yang aman bertujuan untuk mencegah dan meminimalisir dampak dari kecelakaan. Masyarakat sebagai subjek sosial dan hukum harus patuh dan disiplin terhadap standard berkendara yang aman yang telah ditetapkan oleh pemerintah, dengan menerapkan berkendara yang aman, maka akan menciptakan lalu lintas yang lancar dan aman bagi seluruh penggunanya. Sulit memang untuk menerapkan keamanan berkendara, hal ini dikarenakan kesadaran dan kedisiplinan masyarakat yang masih kurang terhadap keamanan berkendara serta kurangnya pemahaman tentang manfaat berkendaraan (Aryo Perdana: 2015).

Permasalahan lalu lintas di kota Bukittinggi cukup rumit. Penduduk yang heterogen menjadi perhatian utama dalam mengatasi problem lalu lintas dan angkutan jalan. Pertumbuhan penduduk yang terjadi setiap tahun, secara otomatis membuat permintaan akan kebutuhan alat transportasi semakin meningkat, baik transportasi umum maupun pribadi. Di tengah kondisi seperti itu, fasilitas angkutan umum juga memprihatinkan sehingga tidak ada pilihan lain bagi para pengguna jalan selain menggunakan kendaraan pribadi.
Bahkan saat ini masyarakat kalangan menengah ke bawah pun tidak kesulitan untuk membeli sepeda motor. Semuanya merupakan akibat dari mudahnya proses pembelian, mulai dari proses administrasi sampai pada harga uang muka untuk motor cicilan begitu murahnya, sehingga mempermudah masyarakat untuk membeli termasuk untuk memenuhi kebutuhan anak mereka (Agoes Dariyo: 2004).

Berdasarkan pengamatan penulis di wilayah penelitian, remaja umumnya telah mempunyai kendaraan sepeda motor sebagai akibat dari kemudahan dalam mengakses pembelian sebuah sepeda motor. Tidak hanya siswa SMA, SMK bahkan siswa SMP dan SD pun juga memiliki sepeda motor, yang mereka gunakan untuk track-trackan, untuk balap liar yang tidak menggunakan perlengkapan bersepeda motor seperti tidak menggunakan helm.

Pelajar umumnya sangat terlihat bebas di jalan raya dalam menggunakan kendaraan roda dua/sepeda motor, bahkan banyak pelajar yang tidak menggunakan helm, memodifikasi kendaran sehingga terlihat tidak sesuai standar pabrik, seperti knalpot racing, tidak memakai kaca spion, dll. Sebagian besar diantara mereka yang tidak membawa STNK sehingga jika pemeriksaan atau operasi lalu lintas yang dilakukan oleh petugas maka banyak terjaring razia (Agoes Dariyo: 2004).

Dan diantara motor-motor tersebut banyak motor yang baru. Hal ini sesuai bunyi Pasal 52 Ayat (2) Undang-Undang Nomor 22 Tahun 2009 Tentang Lalu 
Lintas dan Angkutan Jalan, Modifikasi kendaraan bermotor sebagaimana dimaksud pada ayat (1) tidak boleh membahayakan keselamatan berlalu lintas, mengganggu arus lalu lintas, serta merusak lapis perkerasan/daya dukung jalan yang dilalui.

Pada tanggal 22 Juni tahun 2009 lalu, Pemerintah mengesahkan UndangUndang Nomor 22 Tahun 2009 Tentang Lalu Lintas dan Angkutan Jalan yang baru yang mencabut Undang-Undang Nomor 14 Tahun 1992 dan menyatakannya tidak berlaku lagi. Keberadaan Undang-Undang baru tersebut diharapkan akan memberikan regulasi dalam dunia perlalulintasan dan mampu memecahkan persoalan saat ini yang sulit dipecahkan.

Sosialisasi terhadap undang-undang baru memang sering kali terasa sulit untuk dapat diterapkan. Setiap pengendara sepeda motor harus menggunakan kaca spion standar motor bersangkutan, Pengendara juga diwajibkan menggunakan helm standar berlabel Standar Nasional Indonesia (SNI), serta pengendara sepeda motor diwajibkan menyalakan lampu utama kendaraan di siang hari berdasarkan bunyi Pasal 107 Ayat (2) Undang-Undang Nomor 22 Tahun 2009 Tentang Lalu Lintas dan Angkutan Jalan: "Pengemudi sepeda motor selain mematuhi ketentuan sebagaimana dimaksud pada ayat (1) wajib menyalakan lampu utama pada siang hari” (Pasal 107 Ayat (2) UndangUndang Nomor 22 Tahun 2009).

Penggunaan kendaraan sepeda motor sangat pesat di Indonesia akan tetapi tidak dibarengi dengan peningkatan akan sadar aman berkendara terutama pada para pelajar SMA/SMK/Setara tentang berkendara aman dan memenuhi standar keselamatan. Kesadaran pentingnya aturan berkendaraan motor hanya ada dalam undang-undang yang tidak diketahui pelajar. Bahkan untuk mendapat SIM (Surat Izin Mengemudi) tidak harus bersusah-payah mengikuti prosedur layak mengemudi. Banyak pelajar yang belum cukup umur menggunakan kendaraan bermotor ke sekolah dan bahkan ada yang telah memiliki SIM (Surat Izin Mengemudi). Padahal dalam Pasal 81 ayat (2), (3), (4), dan (5) Undang-Undang Nomor 22 Tahun 2009 tentang Lalu Lintas dan Angkutan Jalan, SIM C disebutkan dengan jelas bahwa syarat permohonan SIM C perseorangan adalah memiliki KTP dan telah berusia 17 tahun.

Lalu lintas di dalam Undang-Undang Nomor 22 Tahun 2009 Tentang Lalu Lintas dan Angkutan Jalan didefinisikan sebagai gerak Kendaraan dan orang di Ruang Lalu Lintas Jalan, sedangkan yang dimaksud dengan Ruang Lalu Lintas Jalan adalah prasarana yang diperuntukkan bagi gerak pindah Kendaraan, orang, dan/atau barang yang berupa Jalan dan fasilitas pendukung.

Permasalahan lalu lintas secara umum meliputi keamanan dan keselamatan lalu lintas yang sangat kurang, kemacetan lalu lintas dan pelanggaran lalu lintas serta ketidak tertiban lalu lintas (C.S.T. Kansil dan Christine: 1995). 
Anny Yuserlina: Penanggulangan Pelanggaran Lalu Lintas Oleh Satuan Lalu Lintas...

Kendaraan adalah suatu sarana angkut di jalan yang terdiri atas kendaraan bermotor dan kendaraan tidak bermotor. Kendaraan bermotor adalah setiap kendaraan yang digerakkan oleh peralatan mekanik berupa mesin selain kendaraan yang berjalan di atas rel, terdiri dari kendaraan bermotor perseorangan dan kendaraan bermotor umum. Kendaraan tidak bermotor adalah kendaraan yang digerakkan oleh tenaga orang atau hewan (Undang-Undang Nomor 22 Tahun 2009 Tentang Lalu Lintas dan Angkutan Jalan) (Ahmad A.K. Muda: 2010).

Menurut Pasal 1 Undang-Undang Nomor 22 Tahun 2009 tentang Lalu Lintas dan Angkutan Jalan satu kesatuan sistem yang terdiri atas lalu lintas, angkutan jalan, jaringan lalu lintas dan angkutan jalan, prasarana lalu lintas dan angkutan jalan, kendaraan, pengemudi, pengguna jalan, serta pengelolaannya. lalu lintas adalah gerak kendaraan dan orang di ruang lalu lintas jalan. Sedangkan angkutan adalah perpindahan orang dan/atau barang dari satu tempat ke tempat lain dengan menggunakan kendaraan di ruang lalu lintas jalan.

Tata tertib lalu lintas ditunjukkan untuk mewujudkan, mendukung, dan memelihara keamanan, keselamatan, ketertiban, dan kelancaran lalu lintas. Berbagai tindak penertiban terus diupayakan para polisi lalu lintas demi mewujudkan ketertiban lalu lintas dan kenyamanan berkendara, serta keselamatan para pengguna jalan raya, baik melalui razia kelengkapan berkendara, kelayakan mengemudi, serta kegiatan-kegiatan diskusi umum dengan tujuan meningkatkan ketertiban dalam berlalu lintas (Fathur Rahim: 2018).

Secara umum dikatakan lalu lintas adalah sebagai urat nadi kehidupan masyarakat yaitu sebagai pendukung aktifitas dan produktifitas yang mensejahterakan kehidupan masyarakat itu sendiri. Namun, dalam kehidupan sehari-hari begitu kompleks masalah lalu lintas. Dari masyarakat yang memanfaatkan jalan sebagai sarana usaha, pengguna jalan, infrastruktur, sistem transportasi, aparat atau petugas yang menangani (Polisi, Dinas Perhubungan, Dinas Pekerjaan Umum), sektor bisnis, tata ruang. Belum lagi masalah alam maupun masalah sosial lainnya. Menangani lalu lintas tidak bisa hanya dari satu sisi saja, harus ditangani secara terpadu dan berkesinambungan (C.S.T. Kansil dan Christine: 1995).

Undang-Undang Nomor 22 Tahun 2009 Tentang Lalu Lintas dan Angkutan Jalan merupakan sebuah paradigma baru dalam pengaturan berlalu lintas dan angkutan jalan yaitu Pendefinisian kembali yang berhubungan dengan lalu lintas dan angkutan jalan. Dalam ketentuan umum Undang-Undang Nomor 22 Tahun 2009 Tentang Lalu Lintas dan Angkutan Jalan memberikan definisi yang lebih tajam dan lebih banyak dari pada Undang-Undang Nomor 14 tahun 1992. Hal ini dapat dilihat dari banyaknya definisi mengenai lalu lintas dan angkutan jalan dalam ketentuan umum UndangUndang Nomor 22 Tahun 2009 Tentang Lalu Lintas dan Angkutan Jalan. 
Setidaknya Undang-Undang Nomor 22 Tahun 2009 Tentang Lalu Lintas dan Angkutan Jalan memberikan 40 definisi yang berkaitan dengan lalu lintas dan angkutan jalan. Dalam Undang-Undang Nomor 22 Tahun 2009 Tentang Lalu Lintas dan Angkutan Jalan ini meluaskan cakupan dan pengaturan lalu lintas dan angkutan jalan. Luas cakupan ini ditandai dengan muculnya beberapa bab baru yang lebih spesifik mengatur mengenai lalu lintas dan angkutan jalan yang sebelumnya tidak diakomodir pada Undang-Undang Nomor 14 Tahun 1992.

Adapun jenis kendaraan bermotor, menurut Undang-Undang Nomor 22 Tahun 2009 Tentang Lalu Lintas dan Angkutan Jalan, Pasal 5 yaitu:

1. Sepeda motor adalah kendaraan bermotor beroda dua dengan atau tanpa rumah-rumah dan dengan atau tanpa kereta samping atau kendaraan bermotor beroda tiga tanpa rumah-rumah.

2. Mobil penumpang adalah setiap kendaraan bermotor yang dilengkapi sebanyak-banyaknya 8 (delapan) tempat duduk tidak termasuk tempat duduk pengemudi, baik dengan maupun tanpa perlengkapan pengangkutan bagasi.

3. Mobil bus adalah setiap kendaraan bermotor yang dilengkapi lebih dari 8 (delapan) tempat duduk tidak termasuk tempat duduk pengemudi, baik dengan maupun tanpa perlengkapan pengangkutan bagasi.

4. Mobil barang adalah setiap kendaraan bermotor selain dari yang termasuk dalam sepeda motor, mobil penumpang dan mobil bus.

5. Kendaraan khusus adalah kendaraan bermotor selain daripada kendaraan bermotor untuk penumpang dan kendaraan bermotor untuk barang, yang penggunaannya untuk keperluan khusus atau mengangkut barangbarang khusus.

Kepatuhan berarti mengikuti suatu spesifikasi, standar atau hukum yang telah diatur dengan jelas yang biasanya diterbitkan oleh lembaga atau organisasi yang berwenang dalam suatu bidang tertentu. Lingkup suatu aturan dapat bersifat internasional maupun nasional, misalnya standar internasional yang diterbitkan oleh ISO ataupun aturanaturan nasional seperti Undang-Undang Nomor 22 Tahun 2009 Tentang Lalu Lintas dan Angkutan Jalan. Dalam Undang-Undang Nomor 22 Tahun 2009 Tentang Lalu Lintas dan Angkutan Jalan terdapat aturan-aturan yang mengatur mengenai lalu lintas dan angkutan jalan. Salah satu aturan tersebut adalah mengenai kewajiban pengendara sepeda motor untuk menyalakan lampu di siang hari yaitu pada Pasal 107 ayat (2). Apabila para pengendara tersebut mengikuti hukum yang diatur dengan jelas di Undang-Undang Nomor 22 Tahun 2009 Tentang Lalu Lintas dan Angkutan Jalan maka pengendara tersebut bisa dianggap patuh.

\section{METODE PENELITIAN}

Dalam penelitian ini penulis menggunakan metode pendekatan yuridis empiris yaitu pendekatan terhadap permasalahan penelitian dari aspek 
Anny Yuserlina: Penanggulangan Pelanggaran Lalu Lintas Oleh Satuan Lalu Lintas...

yuridis dan praktik hukum di lapangan tentang peranan satuan lalu lintas dalam menanggulangi pelanggaran lalu lintas oleh pelajar di Polres Bukittinggi.

Bahwa penelitian ini bersifat Deskriptif, yaitu penelitian yang memberikan data tentang sesuatu atau gejala-gejala sosial yang berkembang di tengah-tengah masyarakat sehingga dengan adanya penelitian ini diharapkan dapat memperoleh gambaran yang menyeluruh, lengkap dan sistematis tentang objek yang akan di teliti.

Setelah semua data berhasil dikumpulkan berdasarkan penelitian yang dilakukan di lapangan, maka data tersebut disatukan untuk kelanjutan diolah sedemikian rupa secara sistematik. Dari pengolahan data yang telah dilakukan, selanjutnya perlu dilakukan analisa sehingga menghasilkan data dalam bentuk uraian kalimat yang kritis dan relevan dengan pemecahan permasalahan. Untuk itu digunakan analisa kualitatif, yaitu hasil penelitian kepustakaan akan dipergunakan untuk menganalisa data yang diperoleh dari lapangan dan kemudian data primer dan data sekunder dianalisa secara kualitatif untuk menjawab permasalahan dalam penelitian ini.

\section{HASIL DAN PEMBAHASAN}

Satuan lalu $\begin{gathered}\text { lintas } \\ \text { dalam } \\ \text { melaksanakan } \\ \text { menanggulangi pelanggaran lalu lintas, } \\ \text { dalam }\end{gathered}$
sesuai dengan Pasal 7 Peraturan Kapolri
Nomor 23 Tahun 2010, satuan lalu lintas
merupakan Unsur pelaksana tugas Pokok
di tingkat Polres. Selanjutnya lebih

ditegaskan pada Pasal 59 Peraturan Kapolri Nomor 23 Tahun 2010, dijelaskan bahwa Satlantas sebagaimana dijelaskan bahwa:

1. Satuan lalu lintas merupakan unsur pelaksana tugas pokok yang berada di bawah Kapolres.

2. Satlantas bertugas melaksanakan Turjawali lalu lintas, pendidikan masyarakat lalu lintas (Dikmaslantas), pelayanan registrasi dan identifikasi kendaraan bermotor dan pengemudi, penyidikan kecelakaan lalu lintas dan penegakan hukum di bidang lalu lintas.

3. Dalam melaksanakan tugas sebagaimana dimaksud pada ayat (2), Sat lantas menyelenggarakan fungsi:
a. Pembinaan lalu lintas kepolisian;
b. Pembinaan partisipasi masyarakat melalui kerja sama lintas sektoral, Dikmaslantas, dan pengkajian masalah di bidang lalu lintas;
c. Pelaksanaan operasi kepolisian bidang lalu lintas dalam rangka penegakan hukum dan keamanan, keselamatan, ketertiban, kelancaran lalu lintas (Kamseltibcarlantas);
d. Pelayanan administrasi registrasi dan identifikasi kendaraan bermotor serta pengemudi;
e. Pelaksanaan patroli jalan raya dan penindakan pelanggaran serta penanganan kecelakaan lalu lintas dalam rangka penegakan hukum, serta menjamin 
Kamseltibcarlantas di jalan raya;

f. Pengamanan dan penyelamatan masyarakat pengguna jalan; dan

g. Perawatan dan pemeliharaan peralatan dan kendaraan.

Berdasarkan hasil wawancara dengan Kanit Laka Polres Bukittinggi Bapak Novandri, S.H Pada Tanggal 12 Januari Pukul 10.00 Wib beliau menyampaikan selain hal diatas juga satuan lalu lintas melakukan hal-hal yang menekan angka pelanggaran lalu lintas yang dilakukan oleh pelajar, antara lain adanya penyuluhan tentang ketertiban berlalu lintas di jalan raya pada saat upacara di sekolah-sekolah yang ada di wilayah hukum Polres Bukittinggi, namun dalam melaksanakan peranannya sebagai satuan lalu lintas yang sesuai aturan yang berlaku. Pada tahun 2016 terjadi 2.241 kasus, pada tahun 2017 terjadi 1.850 kasus, dan pada tahun 2018 terjadi penurunan 1.116 kasus. (Sumber Data Satuan Lalu Lintas Kota Bukittinggi Tahun 2018).

Hasil wawancara dengan salah satu pelajar yang bernama Hidayat yang melanggar lalu lintas, bahwa dia mengetahui apa yang telah dilakukannya adalah sebuah pelanggaran lalu lintas, namun dia merasa bahwa perbuatannya tersebut juga sering dilakukan oleh teman-teman sekolahnya. Dia pun tau efek yang ditimbulkan dari pelanggaran tersebut tidak hanya dari bentuk pelanggaran yang dituangkan dalam Undang-undang saja tetapi ada efek yang ditimbulkan akibat dari pelanggaran tersebut.

Hasil wawancara dengan salah seorang Personil Satuan lalu Lintas Bukittinggi, Bapak Romi, S.H beliau mengatakan Pertumbuhan jumlah kendaraan bermotor di Wilayah Hukum Polres Bukittinggi terus mengalami penurunan dari tahun ke-tahun. Namun kondisi tersebut juga diiringi dengan peningkatan kesadaran tertib berlalu lintas dari masyarakat sebagai pengguna jalan raya, khususnya pelajar di Wilayah Hukum Polres Bukittinggi. Penggunaan kendaraan bermotor di kalangan pelajar yang pada umumnya rata-rata masih dibawah umur sering melakukan tindakan pelanggaran lalu lintas.

Penegak hukum khusus di dalam hukum pidana merupakan proses hukum tentang perbuatan-perbuatan yang menuntut hukum bertentangan dan dapat dihukum menurut ketentuan hukum yang berlaku. Selain itu diatur pula petunjukpetunjuk tindakan yang harus diupayakan untuk kelancaran berlakunya hukum. Peradilan hukum pidana di Indonesia dilaksanakan oleh lima lembaga yaitu polisi, jaksa, hakim, lembaga pemasyarakatan, dan advokasi. Polisi sendiri merupakan salah satu penegak hukum yang mengungkap kasus sebagai modal dasar proses hukum yang selanjutnya di proses oleh jaksa dan hakim di pengadilan. Peraturan hukum akan berjalan sebagaimana mestinya jika ada kesadaran warga masyarakat untuk mematuhi hukum dan penegakan hukum oleh aparat yang berwenang (Giyan 
Anny Yuserlina: Penanggulangan Pelanggaran Lalu Lintas Oleh Satuan Lalu Lintas...

Apandi dan Anom Wahyu Asmorojati: 2014).

Lembaga Kepolisian adalah merupakan organisasi yang disusun secara berjenjang dari tingkat pusat sampai tingkat daerah. Peranan Polisi tidak hanya terbatas dalam artian sebagai alat negara untuk melaksanakan penegakan hukum dalam hal adanya tindak pidana, tetapi juga dalam hal adanya pelanggaran hukum.

Tugas pokok dan fungsi Polri dalam hal penyelenggaraan lalu lintas sebagai suatu urusan pemerintah di bidang registrasi dan identifikasi kendaraan bermotor dan pengemudi, penegakan hukum, operasional manajemen dan rekayasa lalu lintas serta pendidikan berlalu lintas, oleh Kepolisian Negara Republik Indonesia.

Upaya yang dilakukan oleh Polisi lalu lintas dalam menanggulangi pelanggaran lalu lintas yang dilakukan oleh pelajar dapat dilakukan dengan cara: Preventif/upaya pencegahan secara Moralitas, dan Secara abolisionistik, Represif/penegakan hukum. Faktor-faktor yang menjadi hambatan dalam menanggulangi pelanggaran lalu lintas yang dilakukan oleh pelajar yaitu: Masalah kesadaran hukum dan kepatuhan hukum berlalu lintas dikalangan pelajar masih kurang. Dikalangan pelajar masih banyak yang belum mengetahui dan mengerti tentang peraturan berlalu lintas, mengenai pengetahuan berlalu lintas masih belum ada di dalam kurikulum sekolah, masih kurangnya kesadaran hukum masyarakat Bukittinggi, adanya kesempatan pelajar untuk tetap membawa sepeda motornya ke sekolah dengan menitipkan sepeda motornya ke warungwarung yang berada diluar sekitar sekolahnya, masih kurangnya kepedulian pihak sekolah terhadap pelajar yang mengendarai sepeda motor ke sekolah, masih kurang optimalnya pihak Kepolisian memberikan edukasi mengenai lalu lintas ke sekolah-sekolah.

Peranan adalah aspek yang dinamis dari kedudukan atau statusnya. Jika seseorang melaksanakan hak dan kewajibannya sesuai dengan kedudukannya, maka hal ini merupakan ia menjalankan suatu peranan. Keduanya tidak dapat dipisah-pisahkan dan saling bertentangan satu sama lain. Setiap orang mempunyai macam-macam peranan yang berasal dari pola-pola pergaulan hidupnya. Hal tersebut sekaligus berarti bahwa peranan menentukan apa yang diperbuatnya bagi masyarakat kepadanya. Peranan lebih banyak menekankan pada fungsi, penyesuaian diri dan sebagai suatu proses.

Peranan adalah suatu perbuatan seseorang atau sekelompok orang dengan cara tertentu dalam usaha menjalankan hak dan kewajibannya sesuai dengan status yang dimilikinya. Pelaku peranan dikatakan berperan jika telah melaksanakan hak dan kewajibannya sesuai dengan status sosialnya dengan masyarakat. Jika seseorang mempunyai status tertentu dalam kehidupan masyarakat, maka selanjutnya akan ada kecenderungan akan timbul suatu harapan harapan baru. 
Peran di sini adalah sesuatu yang memainkan role, tugas dan kewajiban. Peran merupakan sesuatu yang diharapkan lingkungan untuk dilakukan oleh seseorang atau sekelompok orang yang karena kedudukannya akan dapat memberi pengaruh pada lingkungan tersebut. Peranan menunjukkan keterlibatan diri atau keikutsertaan individu, kelompok yang melakukan suatu usaha untuk mencapai tujuan tertentu atas suatu tugas atau bukti yang sudah merupakan kewajiban dan harus dilakukan sesuai dengan kedudukannya. Peranan Satlantas Polresta berarti menunjukkan pada keterlibatan para pegawai Satlantas Polresta dalam upaya cara tertib berlalu lintas.

Tugas Satlantas sesuai Pasal 2 Peraturan Pemerintah Republik Indonesia Nomor 80 Tahun 2012 tentang Tata Cara Pemeriksaan Kendaraan Bermotor di Jalan dan Penindakan Pelanggaran Lalu Lintas dan Angkutan Jalan yang berbunyi: "Melakukan pemeriksaan kendaraan motor di jalan dan penindakan pelanggaran lalu lintas dan angkutan jalan untuk terciptanya kepatuhan dan budaya keamanan dan keselamatan berlalu lintas".

Sesuai Pasal 12 Peraturan Pemerintah Republik Indonesia Nomor 80 Tahun 2012 tentang Tata Cara Pemeriksaan Kendaraan Bermotor di Jalan dan Penindakan Pelanggaran Lalu Lintas ini pemeriksaan kendaraan bermotor di jalan dapat dilakukan secara berkala setiap 6 (enam) bulan atau insidental sesuai dengan kebutuhan Pemeriksaan kendaraan bermotor di jalan sebagaimana yang telah diatur diatas dilakukan oleh petugas satlantas secara gabungan. Hal ini dilakukan berdasarkan pertimbangan tertentu dengan adanya peningkatan angka pelanggaran dan kecelakaan lalu lintas di jalan, angka kejahatan yang menyangkut kendaraan bermotor, jumlah kendaraan yang tidak memenuhi persyaratan teknis dan persyaratan layak jalan, ketidaktaatan pemilik kendaraan melakukan pengujian kendaraan bermotor pada waktunya, pelanggaran perizinan angkutan umum dan pelanggaran kelebihan muatan angkutan barang, mengenai ini dijelaskan pada Pasal 13 Peraturan Pemerintah Nomor 80 Tahun 2012 Tata Cara Pemeriksaan Kendaraan Bermotor di Jalan dan Penindakan Pelanggaran Lalu Lintas.

Penanggulangan pelanggaran terdiri atas tiga bagian pokok, yaitu :

\section{Pre-Emtif}

Upaya Pre-emtif di sini adalah upayaupaya awal yang dilakukan oleh pihak kepolisian untuk mencegah terjadinya pelanggaran, sebagaimana hasil penelitian penulis, dalam wawancara terhadap polisi sebagai aparat hukum mengenai upaya Polres Kampar dalam menanggulangi terjadinya pelanggaran lalu lintas yang dilakukan oleh pelajar Kanit Laka Polres Bukittinggi Bapak Novandri, S.H, mengatakan bahwa upaya yang dilakukan adalah dengan cara melaksanakan sosialisasi di sekolah-sekolah, melalui ceramah, penyuluhan, maupun upacara dan melakukan sosialisasi di TK guna 
Anny Yuserlina: Penanggulangan Pelanggaran Lalu Lintas Oleh Satuan Lalu Lintas...

memberikan pemahaman etika berlalu lintas di usia dini.

Menurut penulis upaya yang dilakukan polisi tersebut merupakan upaya pencegahan yang baik untuk remaja di usia dini, dimana upaya tersebut merupakan upaya untuk menanamkan nilai-nilai/norma-norma yang baik sehingga norma-norma tersebut terintenalisasi dalam diri seseorang, sehingga meskipun ada kesempatan untuk melakukan pelanggaran/kejahatan tapi tidak ada niatnya untuk melakukan hal tersebut maka hal itu tidak akan terjadi.

\section{Preventif}

Preventif adalah tindak lanjut dari upaya pre-emtif. Dalam upaya pre-emtif yang ditekankan adalah menghilangkan kesempatan untuk dilakukannya kejahatan. Dalam hal ini keberadaan polisi pada setiap pos keamanan yang berada di jalan-jalan sangatlah efektif dalam hal menutup kesempatan bagi para pelajar yang belum cukup umur dan/atau remaja yang belum memiliki surat-surat, untuk dapat membawa kendaraan bermotor di jalan. Selain itu juga dilakukan pengawasan dengan cara swiping. Kanit Laka Polres Bukittinggi Bapak Novandri, S.H mengatakan bahwa swiping biasanya dilakukan pada saat ada penugasan dari atasan, yaitu dilakukan pada saat ramadhan (operasi ketupat), pada saat natalan (operasi lilin), (operasi simpati) setiap 6 bulan sekali dan swiping rutin (operasi patuh).

Dari sini sebenarnya sudah dapat dilihat bahwa dengan adanya jadwal swiping yang sedemikian rupa seharusnya sudah tidak ada lagi pelanggaran lalu lintas yang dilakukan oleh anak karena dengan penjagaan yang ketat anak tidak akan berani untuk mengendarai kendaraan di jalan-jalan.

\section{Represif}

Upaya ini dilakukan pada saat telah terjadinya tindak pidana atau kejahatan yang tindakannya berupa penegakan hukum dengan menjatuhkan hukuman. Dalam hal ini apabila polisi menemukan anak dibawah umur yang membawa sepeda motor maka polisi akan memberikan tilang terhadap anak tersebut. Kanit Laka Polres Bukittinggi Bapak Novandri, S.H mengatakan bahwa dengan melaksanakan sosialisasi di sekolah-sekolah, melakukan penindakan dengan tilang apabila menemukan pelanggaran kepada pelajar yang menggunakan sepeda motor guna memberikan efek jera sehingga si anak tidak mengulangi lagi.

Dengan diadakannya sosialisasi di sekolah maka akan memberikan pengetahuan lebih awal sehingga pelajar lebih tahu dan memahami arti penting saat berlalu lintas. Sedangkan dengan cara tilang, anak tersebut akan tahu bahwa sebenarnya belum diperbolehkan untuk berkendara karena belum cukup umur dan belum tahu betul akibat jika berlalu lintas tidak sesuai dengan aturan, tilang tersebut merupakan upaya penanggulangan yang paling efektif. Adapun ketika anak menggunakan sepeda motor dengan kecepatan tinggi dengan sengaja untuk menghindari petugas polisi maka polisi 
juga dapat menindaki anak tersebut dengan cara mengejar anak tersebut dengan motor BM. Dimana motor BM itu merupakan salah satu alat kelengkapan tugas dari polisi, dimana motor itu digunakan untuk berpatroli di samping itu juga pengejaran terhadap pelanggaran. Tetapi tidak semua polisi lalu lintas mendapatkan motor BM karena banyak pula motor yang sudah rusak sehingga tidak dapat digunakan lagi.

Dalam upaya pelanggaran tersebut diatas terdapat beberapa faktor penghambat bagi pihak kepolisian dalam hal melakukan upaya penanggulangan pelanggaran lalu lintas yang dilakukan oleh pelajar. Sebagaimana hasil penelitian penulis, Kanit Laka Polres Kampar Bukittinggi Bapak Novandri, S.H mengatakan bahwa faktor yang menjadi penghambat bagi pihak kepolisian adalah belum ada dukungan sepenuhnya dari orang tua bila ada pelajar yang melakukan pelanggaran lalu lintas, orang tuanya keberatan anaknya di tilang, kadang si remaja juga tidak mau tahu dengan kondisi/situasi yang ada (membandel).

Oleh karena itu, penegakan hukum lalulintas dan angkutan jalan telah menjadi keharusan bagi para pelaksana dan penegak hukum lalulintas dan angkutan jalan, agar pelanggaran lalu lintas terus diminimalisir. Maka dari sisi kondisi tersebut perlu ditingkatkan pula peranan Polisi Lalu Lintas dalam penegakan hukum tersebut (Megawati Barthos: 2018).

\section{SIMPULAN}

Satuan lalu lintas $\begin{array}{r}\text { dalam } \\ \text { dalam }\end{array}$
melaksanakan peranan lintas
menanggulangi pelanggaran lalu
sudah dilaksanakan sesaui dengan aturan
perundang-undangan namun belum
efektif karena bahwa pihak kepolisan
dalam hal ini tidak begitu tegas dalam
menangani kasus pelanggaran yang
dilakukan oleh remaja dikarenakan remaja
tersebut dilarang orang tuanya untuk
ditahan padahal sebagai penegak hukum
ia tidak seharusnya mengiyakan hal
tersebut karena sudah jelas anak itu
melakukan pelanggaran/kesalahan dan
seharusnya ia tetap menjalankan tugasnya
sesuai dengan aturan yang ada.

\section{DAFTAR PUSTAKA}

Agoes Dariyo, 2004, Psikologi Perkembangan Remaja, Ghalia Indonesia, Jakarta.

C.S.T. Kansil, 1995, Disiplin Dalam Berlalu Lintas di Jalan Raya, Rineka Cipta, Jakarta.

M. Karyadi, 1990, Mengurus Kejahatan Pelanggaran Lalu Lintas, Dislitbang Mabes Polri, Jakarta.

R. Soesilo, 1985, Krimininologi (Pengetahuan Tentang Sebab-sebab Kejahatan), Politeia, Bogor.

Soerjono Soekanto, 1980, Pokok-pokok Sosiologi Hukum, PT Raja Grafindo, Jakarta.

Fathur Rahim, 2018, Peranan Unitlantas Polsek Muara Jawa Dalam Meningkatkan Ketertiban Berlalu Lintas Pada Masyarakat Kecamatan Muara Jawa Kabupaten Kutai Kartanegara, Hlm 86-99. 
Anny Yuserlina: Penanggulangan Pelanggaran Lalu Lintas Oleh Satuan Lalu Lintas...

Aryo Perdana, 2015, Peran Guru Dalam

Pembentukan Perilaku Santun Berlalu Lintas Pada Siswa, Hlm. 45-57

Megawati Barthos, 2018, Peran Polisi Lalu Lintas Dalam Meningkatkan Kesadaran Hukum Pengendara Sepeda Motor Di Wilayah Polres Jakarta Pusat Berdasarkan Undang-Undang Nomor 22 Tahun 2009 Tentang Lalu Lintas Dan Angkutan Jalan, Jurnal LexLibrum, Vol. IV, No. 2, Juni 2018, Hlm. 739-757

Giyan Apandi dan Anom Wahyu Asmorojati, 2014, Peranan Polisi
Lalu Lintas dalam Meningkatkan Kedisiplinan Berlalu Lintas Pengguna Kendaraan Bermotor di Wilayah Kepolisian Resort Bantul, Jurnal Citizenship, Vol. 4 No. 1, Juli 2014.

Ayu Yohana Putri, 2015, Efektivitas Sanksi Terhadap Pelanggar Marka Jalan Berdasarkan UndangUndang Nomor 22 Tahun 2009 Tentang Lalu Lintas Dan Angkutan Jalan Oleh Kepolisian Resor Kota Pekanbaru, Jomfakultas Hukum Volume II Nomor II Oktober 2015 